JULIE MIDDLETON is an

Auckland journalist and former

advocacy and communications

officer for the Human Development

Programme at the Secretariat of the

Pacific Community, Noumea.

\section{A fair go for Pacific women role models}

Pasifika Women: Our stories in New Zealand, by Sandra Kailahi. Auckland: Reed, 2007, 192 pp. ISBN 9780790011806.

$\mathrm{P}$ ASIFIKA women are the backbones of their communities in the islands and in New Zealand. But so often, in New Zealand as in their homelands, their contributions and opinions have been invisible or under-documented.

Part of this is the good old gender hierarchy that can act to confer lesser status on Pacific women than Pacific men; part of it is the self-effacement of Pacific women. Another part is a Palagi-centred media, and a publishing industry which has been slow to understand the value of such a book and the potential size of its market.

The 2006 Census told us that 265,974 people identified with the Pacific peoples ethnic group - 6.9

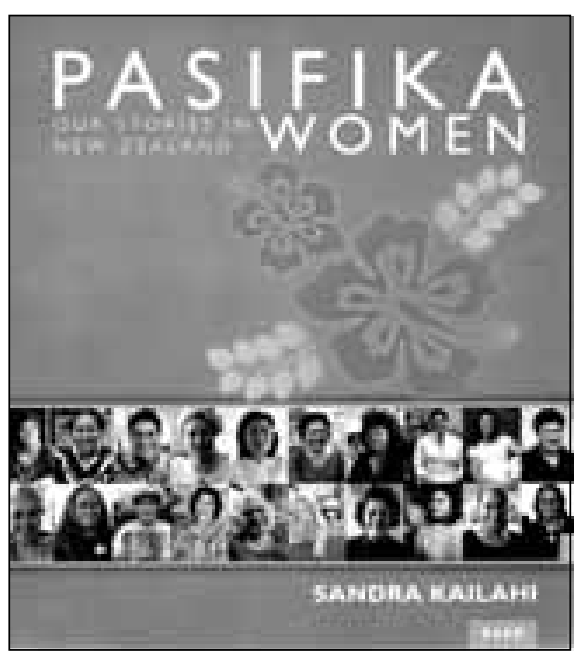

percent of the total New Zealand population. They need to see more of themselves and their role models - as does the rest of New Zealand.

This book, then, is welcome. The author, New Zealand-born television journalist Sandra Kailahi, who describes herself as being of Tongan and New Zealand descent, is a Fair Go staffer who formerly worked for Tagata Pasifika. This is her first book.

With the assistance of a $\$ 3000$ Creative New Zealand grant, the Aucklander has profiled 20 Pasifika women with public status, and in doing so goes a good way towards documenting Pacific women's contribution to New Zealand life.

Her subjects range from the wellknown, such as Minister of Pacific Affairs Luamanuvao Winnie Laban, 
to less high-profile women such as Tofilau Esther Tofilau, the world's only Pacific Island woman bodybuilding judge. ${ }^{1}$ Some of them have always had New Zealand passports; some migrated.

Their first-person, often candid accounts roam from childhood to the present, from the private sphere to public life, and place emphasis on the input of parents and wider family - Kailahi identifies parents and village links at the top of each chapter.

The interviewees outline how they attained their success, and between them highlight and comment on a range of important issues affecting Pacific women here and in the islands.

These include practical and cultural issues adapting to different ways of life; the low numbers of Pacific women in decision-making; the influence of religion; racism; gender equality and the roles of men and women; maintaining cultural traditions far from home, and how notions of status in Pacific society affects the way people communicate.

This book's orientation towards achievers makes it something of a de facto primer on how to succeed, and this is reinforced by the separate boxing of a pithy quote as well as a piece of advice. Here is Ali'itasi Foleni Dutt, New Zealand's top heavyweight boxer:
'I know some people think I shouldn't be boxing because it's wrong for women, let alone a Samoan woman, to box. I feel sorry for them and my heart goes out to them ... they can't see out of the box they are living in. If only they could see what they can achieve and not what they can't.'

There are also rare chances to find out about those whose public lives require distance-for example, Judge Ida Malosi, like all judges, keeps a low public profile so getting her into this book is a coup for Kailahi.

That said, the book does not take a rigorously journalistic approach. The questions Kailahi has posed can only be surmised, and she has avoided some of the obvious (and tough) ones.

The problem with this firstperson biographical take without third-person commentary to fill the gaps allows any moa in the room to be skirted, and this tends to leave the reader with the frustrating sense that the picture is incomplete.

You can infer that Kailahi has had to draw a delicate balance between reader interest in the complete story and the subject's right not to unearth painful memories - or be put in a position where they might refuse to participate.

For example, Judge Malosi discusses her happy marriage ('so in 
love after 25 years') without naming her husband. He is former senior sergeant Anthony Solomona, whose assault conviction in 2005 led to an inquiry into so-called 'sick' police culture. (Solomona was also the person about whom disgraced Herald on Sunday journalist John Manukia fabricated interviews the same year).

A journalistic approach would have ensured that these facts were acknowledged, even briefly, and, ideally, would have encouraged some explanation of how Judge Malosi dealt with the upheaval the issues must have caused. In another example, the fascinating and candid Rev Feiloaigamatausala Janette Taule'ale'ausumai-who talks bravely and openly about her experience of mental ill-healthtalks subsequently about 'some bad experiences I had endured when I was a young woman in the church' which caused her 'flashbacks' and 'trauma'.

She says that those experiences and her ill-health are linked-and that she is 'fine now' - but there is no indication as to whether the author of these experiences has been dealt with. I finished her story worrying that maybe something remained unresolved.

On the publishing side, Reed's editors have been disappointingly sloppy, allowing all sorts of spelling, grammatical and factual errors to make it to print. This undermines the book's credibility and that of Reed. (It is, however, not the only publisher that can plead guilty here; half-hearted editing seems to have become a trend in New Zealand.)

For example, Matafetu Togakilo Smith, a weaver, talks about going to the 1999 South Pacific Arts Festival in Noumea. The festival was actually in 2000 (it happens every four years) and its proper name is the Festival of Pacific Arts.

In the next sentence, someone talks about the Northern Territories in Australia (should be Territory). Someone has a 'breach baby', and another talks about setting 'precedence'.

The images in the book are blackand-white portraits by Elam graduate Eimi Tamua - the key here has been strong and simple settings-and family photos. The book also includes a short but useful glossary of common words in Maori and Pacific Island languages used throughout the book.

Overall, Pasifika Women is an interesting, personable and valuable documentation of the achievements of New Zealand's high-achieving Pacific women. The hope now is that it is widely read. 


\section{Note}

1. Hon. Luamanuvao Winnie Laban, MP; Mihi Joy Wells, amateur body board champ; Matafetu Togakilo Smith, weaver; Soana Pamaka, principal; Rev. Feiloaigamatausala Janette Taule'ale'ausumai, minister; Luisa Avaiki, rugby league player; Faaniniva Tapaau Faasisina Faapopoo Retimanu, radio newsreader; Mere Tapaeru Tereora, community activist; Frances Campbell, local body councilor; Ida Marie Malosi, judge; Ali'itasi Foleni Dutt, heavyweight boxer; Debbie Ryan, doctor; Fanaura Kimiora Kingstone, human rights worker; Penita Davies, karate champion; Ali'imuamua Sandra Alofivae, lawyer; Lily Aitui Laita, artist and teacher; Tofilau Esther Tofilau, bodybuilding judge; Emeline Afeaki-Mafile'o, social policy strategist; Lino Nelisi, children's author; Linda Tuumuliga Vagana, former national netballer.

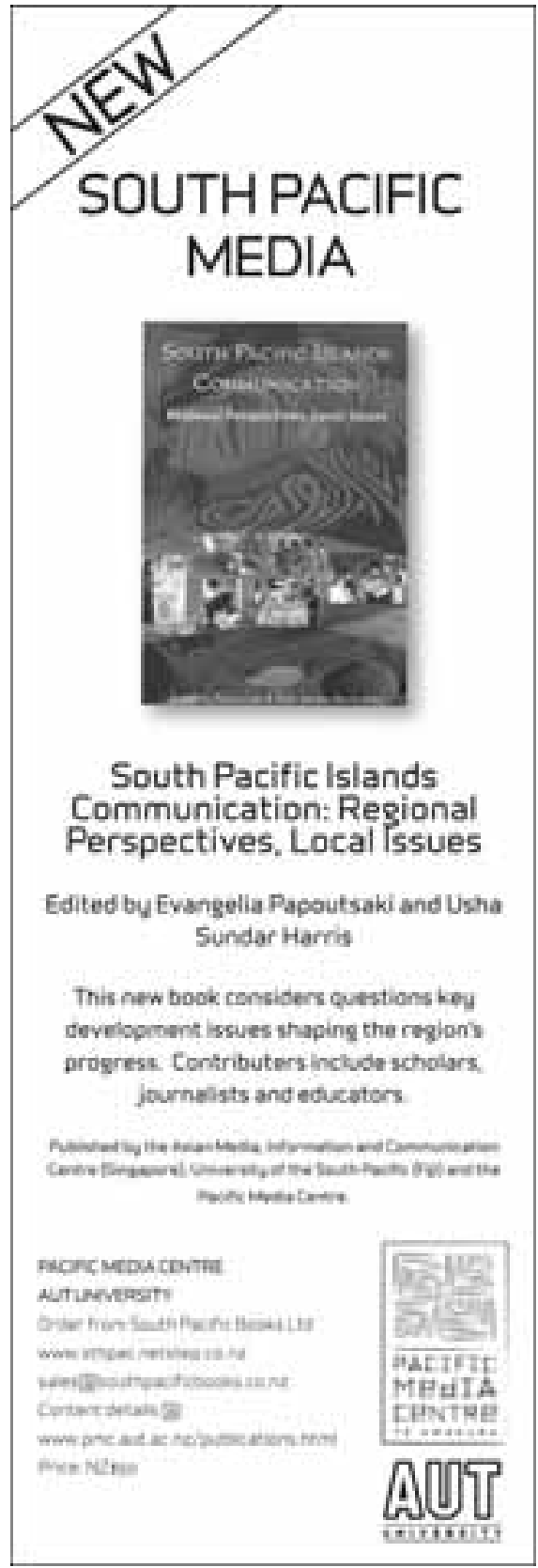

